\title{
Kinerja Karyawan Ditinjau dari Kompensasi Langsung dan Kompetensi Studi Kasus pada PT. Mandiri Tunas Finance Palembang
}

\author{
Tri Darmawati \\ Universitas PGRI Palembang \\ Email : tridarmawati@univpgri-palembang.ac.id \\ Sherly \\ Universitas PGRI Palembang \\ Email:sherlyrehs@gmail.com \\ Tri Sinarti \\ Universitas PGRI Palembang \\ Email : trisinarti1976@gmail.com
}

\begin{abstract}
This research aims to determine the effect of direct compensation and competence on employee performance at PT. Mandiri Tunas Finance Palembang. Distribution of questionnaires using google form with 56 respondents. The sampling method in this research uses a saturated sampling method. This research method uses an associative approach, which is looking for bonding patterns or patterns of influence between variables on one object, to recognize the influence between independent and dependent variables. The method of collecting information is a questionnaire. The variables studied were employee performance as the dependent variable, direct compensation, and competence as the independent variable. Information that has been processed using the SPSS program produces a regression equation $\mathrm{Y}=4,898+0.369 \mathrm{X} 1+0,503 \mathrm{X} 2$. Based on the results of the $\mathrm{t}$ test, it was found that $\mathrm{t}$ count was 3.264 for direct compensation and 4.362 for competence so that direct compensation had a significant effect on employee performance and competence had a significant effect on employee performance. In addition, the f test results in 34,300 so that direct compensation and competence together have a significant effect on employee performance.
\end{abstract}

Keywords: Direct compensation, competence, performance

\begin{abstract}
Abstrak
Riset ini bertujuan mengetahui pengaruh kompensasi langsung dan kompetensi terhadap kinerja karyawan pada PT. Mandiri Tunas Finance Palembang. Penyebaran kuesioner memakai google form dengan 56 responden. Metode pengambilan sampel dalam riset ini memakai metode sampling jenuh. Metode riset ini memakai pendekatan assosiatif ialah, mencari pola ikatan atau pola pengaruh antar variabel pada satu objek, agar dapat mengenali pengaruh antar variabel bebas dan terikat. Metode pengumpulan informasi ialah, kuesioner. Variabel yang diteliti kinerja karyawan selaku variabel terikat, kompensasi langsung serta kompetensi selaku variabel bebas. Informasi yang sudah diolah dengan memakai program SPSS menghasilkan persamaan regresi Y= $4,898+0,369 X_{1}+0,503 X_{2}$. Berdasarkan hasil pada uji t diperoleh $t_{\text {hitung }} 3,264$ untuk kompensasi langsung dan 4,362 untuk kompetensi sehingga kompensasi langsung mempengaruhi signifikan terhadap kinerja karyawan serta kompetensi mempengaruhi signifikan terhadap kinerja karyawan. Selain itu pada uji f yang hasilnya 34,300 sehingga kompensasi langsung dan kompetensi secara bersama sama mempengaruhi signifikan terhadap kinerja karyawan.
\end{abstract}

Kata Kunci: Kompensasi langsung, kompetensi, kinerja

\section{Pendahuluan}

Sebuah organisasi tidak akan terlepas dari berbagai masalah yang terkait dengan fungsi perusahaan pada setiap perjalanan bisnis. Masalah dapat berasal dari beberapa aspek, antara lain peran organisasi yang meliputi faktor permintaan, faktor personal, faktor pemasaran dan faktor permodalan serta peran manajemen, yang meliputi manajemen perusahaan, manajemen dan organisasi. Pengaruh dari dalam dan luar organisasi akan mempengaruhi semua lini. Sebagai aset sumber daya manusia, keberhasilan seorang pegawai merupakan hasil kerja seorang pegawai dengan kualifikasi dan kompetensi yang berbeda untuk melakukan pekerjaannya. Pemanfaatan sumber daya manusia dalam aktivitas organisasi dilingkungan masyarakat umum maupun dilingkungan bisnis ialah aspek utama, disamping 
bermacam sumber daya dan sumber energi yang lain. Sumber daya manusia akan menjadi pengerak terbesar dalam kemajuan suatu organisasi maupun kegiatan bisnis. Sinambela (2018) menyatakan bahwa manusia menjadi pemeran paling besar yang membantu menggerakkan sumber daya lainnya. Untuk melakukan pengelolaan berbagai sumber daya diperlukan sumber daya manusia yang berkualitas. Sumber daya manusia yang banyak pada suatu organisasi ataupun kegiatan bisnis dapat berjalan dengan baik jika sumber daya manusianya memiliki kompetensi. Dimana saat ini untuk mendapatkan sumber tenaga kerja yang handal dan memiliki kinerja yang baik semakin susah didapatkan, kendala lain bagi perusahaan adalah mempertahankan tenaga tenaga kerja yang sudah dimiliki.

Untuk mempertahankan sumber sumber daya manusia yang sudah dimiliki ada beberapa faktor yang mempengaruhi antara lain, kompensasi langsung, kompetensi dan kinerja karyawan. Dengan pemberian kompensasi langsung yang sesuai dapat menimbulkan dorongan dari dalam diri karyawan untuk dengan senang hati memberikan segala kemampuan yang diharapkan organisasi ataupun perusahaan. Memiliki Sumber daya manusia dengan kinerja yang baik dan optimal pada akhirnya akan menciptakan kinerja karyawan yang baik pula, kinerja itu sendiri adalah hasil yang dicapai seorang karyawan dalam satu kurun waktu tertentu. Menurut Bintoro \& Daryanto (2017) kata kinerja berasal dari kata performa aktual yang maksudnya prestasi kerja ataupun prestasi seharusnya yang bisa dilakukan oleh seorang.

Kompetensi sangatlah berarti dalam dunia bisnis selaku acuan perekrutan karyawan. Kompetensi merupakan sesuatu keahlian buat melakukan ataupun melaksanakan kegiatan/ pekerjaan/ tugas. Pada PT. Mandiri Tunas Finance Palembang dalam memperkirakan kinerja seseorang karyawan salah satunya dapat dilihat dari riwayat pekerjaannya, yang diartikan dalam hal ini merupakan pengetahuan serta pengalaman di tempat kerja yang dilalui ataupun dengan kata lain semakin besar pengetahuan serta pengalaman yang dimilikinya, sehingga karyawan tersebut menjadi kompeten dalam segi pekerjaannya dan menimbulkan kinerja yang smakin baik. Tetapi jika ingin lebih maksimal dapat diimbangi dengan tingkatan pengetahuan yang diperbarui, sebab ilmu pengetahuan terus tumbuh, sama halnya dengan masa yang terus berubah.

Pada PT. Mandiri Tunas Finance masih terus mengupayakan untuk terus optimalkan pemberian kompensasi pada karyawan. Kompensasi langsung yang sepatutnya ialah balas jasa yang sesuai dengan kinerja karyawan, pemberian kompensasi langsung sebaiknya mempertimbangkan masa kerja, serta jabatan kerja dan ada banyak perbandingan diantara karyawan lama serta karyawan baru dalam kasus pemberian pendapatan, selaku wujud dari kompensasi langsung yang diperkenankan oleh industri supaya cocok dengan UMR (Upah minumum rata- rata) yang berlaku. Berikut merupakan masa kerja di PT. Mandiri Tunas Finance Palembang.

Tabel 1. Masa kerja karyawan

\begin{tabular}{|l|l|l|}
\hline No & Masa kerja & Jumlah \\
\hline 1. & $3-4$ tahun & 9 orang \\
\hline 2. & $2-3$ tahun & 19 orang \\
\hline 3. & $1-2$ tahun & 20 orang \\
\hline 4. & $<1$ tahun & 8 orang \\
\hline \multicolumn{2}{|l|}{ Jumlah } & 56 Orang \\
\hline
\end{tabular}

Sumber: PT. Mandiri Tunas Finance, 2020

Tabel 1 memperlihatkan bahwa masa kerja karyawan terlama pada PT. Mandiri Tunas Finance Palembang adalah 4 tahun. Kompensasi yang diterima karyawan berupa gaji untuk 56 karyawan terdapat kesamaan, yang membedakan hanyalah pada pemberian upah, insentif, bekerja diluar jam kantor dan bonus. PT. Mandiri Tunas Finance Palembang memiliki karyawan tetap serta kontrak. 
Perusahaan akan memenuhi pemberian nilai kompensasi langsung berdasarkan kemampuan perusahaan yang menyesuaikan peraturan pemerintah dan berdasarkan kinerja karyawan.

Tabel 2. Nominal kompensasi langsung

\begin{tabular}{|l|l|c|c|c|}
\hline \multirow{2}{*}{$\begin{array}{l}\text { Bentuk Kompensasi } \\
\text { Indikator }\end{array}$} & \multicolumn{3}{|c|}{ Tahun } \\
\cline { 3 - 5 } & Gaji & $\mathbf{2 0 1 7}$ (dalam Rp) & $\mathbf{2 0 1 8}$ (dalam Rp) & $\mathbf{2 0 1 9}$ (dalam Rp) \\
\cline { 2 - 5 } & Upah & 1.821 .600 .000 & 1.869 .600 .000 & 1.728 .000 .000 \\
\cline { 2 - 5 } Langsung & Insentif/Lembur & 806.000 .000 & 34.500 .000 & 45.000 .000 \\
\cline { 2 - 5 } & Bonus & 14.000 .000 & 147.200 .000 & 708.000 .000 \\
\hline Jumlah & 2.666 .000 .000 & 2.705 .300 .000 & 14.000 .000 \\
\hline Persentase & - & $20.14 \%$ & $7,77 \%$ \\
\hline
\end{tabular}

Sumber: Data sekunder yang diolah, 2020

Pada tabel 2 memperlihatkan pemberian kompensasi langsung pada karyawan dari tahun 2017-2019. Terjadi kenaikan pada tahun 2018 sebesar 20,14\% namun terlihat di tahun 2019 terjadi penurunan sebesar $7,77 \%$. Hal itu dapat mempengaruhi kinerja karyawan.

Dalam hal kompetensi tenaga kerja yang mempunyai tingkat pengetahuan dan keahlian yang besar wajib disesuaikan oleh organisasi maupun industri, jabatan tertentu wajib mempunyai kompetensi yang dibutuhkan buat melakukan pekerjaan secara efektif dan efisien. Begitu juga sikap beberapa karyawan dalam berkomunikasi masih kurang optimal maka diharapkan agar memberikan pelayanan yang baik kepada nasabah PT. Mandiri Tunas Finance Palembang yang bergerak dalam bidang jasa di mana kemampuan SDM nya sangat menentukan sehingga akan berdampak pada perusahaan dan berdampak pula kurang optimalnya kinerja karyawan.

\section{Literatur Review}

\subsection{Kompensasi langsung}

Bagi Wibowo (2014) kompensasi ialah penghargaan yang diberikan sebab terdapatnya pemanfaatan tenaga ataupun jasa yang sudah dicoba para pekerja. Kompensasi yakni totalitas keseluruhan yang di usulkan organisasi bagi para pekerja sebagai imbalan atas pemanfaatan tenaga kerjanya. Wibowo (2014) juga menyampaikan bahwa kompensasi merupakan apa yang diterima pekerja selaku nilai ubah terhadap kontribusinya pada organisasi ataupun industri dan sesuatu kemauan ataupun kepuasan yang menjadikan terdapatnya ikatan antara kompensasi atas kinerja, dengan diberikannya kompensasi buat para pekerja akan menjadikan rasa penghargaan untuk pekerja bersumber pada kinerja serta bukan berdasatkan senioritas ataupun jumlah jam kerja.

Hal-hal dapat mempengaruhi kompensasi bagi Hasibuan (2017) yaitu: permintaan serta penawaran tenaga kerja, keahlian serta ketersediaan industri, serikat buruh maupun organisasi pegawai, produktivitas kerja para pegawai, pemerintah dan peraturan undang- undang dan Keppres, anggaran hidup keadaan jabatan karyawan, pendidikan serta pengalaman kerja, keadaan perekonomian secara keseluruhan serta, tipe dan watak pekerjaan. Pada dasarnya kompensasi bisa diklasifikasikan dalam 2 kelompok ialah langsung serta tidak langsung. Kompensasi langsung terdiri dari pendapatan pokok, pendapatan variabel, dan upah serta seluruh wujud kompensasi yang langsung diterima karyawan. Kompensasi tidak langsung terdiri dari: tunjangan, asuransi, dana cuti, dan dana pensiunan serta wujud kompensasi diberikan secara tidak langsung tetapi dialami manfaatnyaa serta tercantum dalam pengeluaran karyawan.

Menurut Kadarisman (2014) cara pemberian kompensasi yang bagus dengan sistem yang dapat menanggung nilai pemenuhan bagi semua anggota organisasi atau instansi. Dimana akhirnya dapat membuat organisasi/instansi mendapatkan pekerja yang sesuai keingginan, menggunakan sebagian tenaga kerja yang memiliki kinerja yang besar bagi tujuan bersama. Dari penjelasan tersebut dapat 
diketahui bahwa penyampaian kompensasi diperlukan banyak masukan diantaranya apakah penyampaian kompensasi tersebut mengikuti pada keperluan tenaga kerja atau berdasarkan kualitas kewajiban pekerja. Hasibuan (2017) mengatakan indikator kompensasi meliputi: (1) permintaan dan pasokan pasar tenaga kerja; (2) kapasitas dan ketersediaan perusahaan; (3) serikat pekerja atau organisasi pekerja; (4) produktivitas tenaga kerja; (5) aturan pemerintah; 6) biaya hidup sesuai dengan posisi pekerja; (7) pendidikan dan pengalaman; 8) kondisi perekonomian nasional; 9) jenis serta sifat pekerjaan.

\subsection{Kompetensi}

Kompetensi secara universal merupakan suatu kecakapan, penguasaan, serta keahlian. Sebutan kompetensi merujuk pada sifat atau karakter seseorang untuk menjadi sukses dalam melakukan pekerjaan. Sebagian pihak umumnya memakai sebutan kompetensi ialah keahlian dalam melaksanakan kinerja. Fahmi (2016) mengatakan kompetensi merupakan potensi yang ada atau dipunyai seseorang secara pribadi dan mempunyai nilai berharga yang keseluruhannya bisa dilaksanakan dari hasil karya dan pemikiran yang telah dilakukan.

Menurut Darmawati (2013) kompetensi merupakan keadaan diri seseorang untuk melakukan sesuatu berlandaskan keahlian dan pemikiran serta ditunjang cara bersikap atau cara melakukan sesuatu kegiatan yang pengamalannya dilakukan berdasarkan tugas yang telah ditetapkan.

Bagi Moeheriono (2014) kompetensi di dideskripsikan selaku sifat yang membuat seorang berhubungan dengan daya guna kinerja sesorang dalam pekerjaannya ataupun ciri dasar orang yang memiliki sebab akibat ataupun selaku kausalitas atas tolak ukur sebagai rujukan, efisien ataupun berkinerja optimal ataupun terbaik dilokasi kerja ataupun di suasana tertentu. Ada beberapa faktor yang mempengaruhi kompetensi karyawan antara lain, komitmen orang terhadap pencapaian tujuan hidupnya (motif), ketertiban, konsep diri, kedudukan sosial, kualitas mentor, keharmonisan ikatan keluarga. Dari seluruh faktor tersebut, komitmen dalam mencapai tujuan hidup seorang merupakan salah satu faktor yang sangat kokoh memastikan tingkatan kemampuan kompetensi seorang dan pada akhirnya mempengaruhi terhadap kinerjanya. Oleh karena itu diperkirakan kompetensi karyawan bisa digunakan untuk memprediksi karyawan yang mempunyai kinerja yang baik serta kurang baik didasarkan pada standar yang digunakan. Wibowo (2014) mengatakan indikator kompetensi ada 3 (tiga) yaitu: pengetahuan, keterampilan, dan sikap.

\subsection{Kinerja Karyawan}

Menurut Moeheriono (2014) kinerja merupakan gambaran tentang tahapan proses kegiatan suatu rencana atau prosedur guna terwujudnya sasaran, tujuan, visi dan misi organisasi dan tercantum didalam program yang akan dicapai dan disampaikan melalui perencanaan strategis dalam organisasi ataupun instansi.

Mangkunegara (2014) menerangkan kalau aspek kinerja terdiri dari aspek internal serta aspek eksternal. Bisa dimaksud kalau aspek internal ialah aspek yang berasal dari karyawan, dimana fitur internal ini dikaitkan dengan sifat seseorang serta keahlian seorang, sehingga keterampilan pekerja terkait langsung. Selanjutnya ialah aspek eksternal, ialah aspek kinerja pekerja yang terbawa- bawa dari luar, semacam pemberian kompensasi.

Pemikiran lain di informasikan oleh Inova \& Jayanti (2019) yang menyatakan terdapat 4 aspek yang pengaruhi kinerja yaitu: 1) mempertimbangkan bakat, pengalaman dan keahlian karyawan dalam kasus kurangnya keterampilan, pengetahuan dan keahlian yang menyebabkan gangguan kinerja, persiapan, perbaikan dan persyaratan pelatihan; 2) Pertimbangan sumber daya yang tersedia mencakup aspek-aspek yang dapat memengaruhi keberhasilan karyawan ketika layanan yang dapat diakses hanya tersedia bagi karyawan. Instrumen ini dapat digunakan di kantor, kantor, staf pendukung; 4) Aspek inspiratif karyawan, yaitu motivasi karyawan, disiplin minat dan kemampuan. 
Menurut Bintoro \& Daryanto (2017) kinerja karyawan yaitu penyampaian sesuatu yang bernilai untuk kemajuan organisasi maupun perusahaan dalam pencapaian tujuan, oleh karena itu semua aktivitas dikelola dan dilaksanakan organisasi untuk mencapainya. Oleh sebab itu, apabila tanpa arah dan sasaran yang ditentukan menyebabkan kinerja pegawai atau kelompok tidak dapat dipahami karena standar tidak digunakan.

Edison (2016) menyatakan kinerja adalah tolak ukur dari suatu sistem yang mengacu dan di ukur dari periode yang ditentukan atau yang telah disepakati sebelumnya. Adapun indikator kinerja yang dikemukakan oleh Bintoro \& Daryanto (2017) yaitu: kualitas, kuantitas, ketepatan waktu, efektifitas, dan kemandirian.

\subsection{Kerangka Pemikiran}

Kerangka pemikiran merupakan sesuatu diagram yang menjabarkan secara alur logika berjalan suatu riset. Ada pula cerminan dari kerangka pemikiran tersebut:

Gambar I. Kerangka Pemikiran

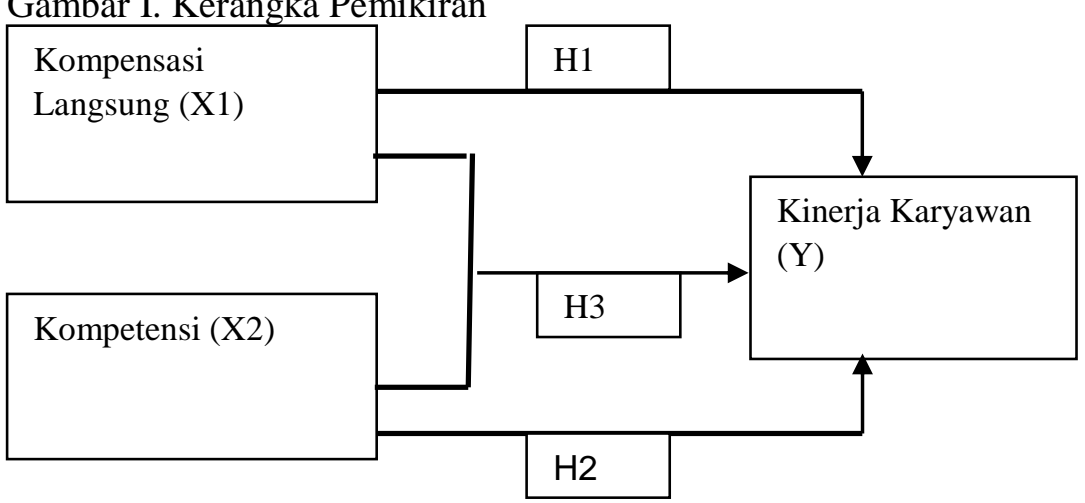

Sumber: Data sekunder yang diolah, 2020

Menurut Sugiyono (2017) hipotesis yaitu dugaan sementara atas hasil peneitian yang dilakukan. Hipotesis ini disampaikan sebagai jawaban sementara yang di informasikan atas dasar bersumber pada teori yang bersangkutan, belum bersumber dari fakta empiris ialah didapat lewat pengumpulan informasi. Bersumber pada kajian teori serta kerangka berpikir riset, hingga diformulasikan hipotesis, selaku berikut:

$\mathrm{H}_{1}$ : kompensasi langsung $\left(\mathrm{X}_{1}\right)$ diduga berpengaruh signifikan terhadap kinerja karyawan (Y) PT. Mandiri Tunas Finance Palembang.

$\mathrm{H}_{2}$ : kompetensi $\left(\mathrm{X}_{2}\right)$ diduga berpengaruh signifikan terhadap kinerja karyawan (Y) PT. Mandiri Tunas Finance Palembang.

$\mathrm{H}_{3}$ : kompensasi langsung $\left(\mathrm{X}_{1}\right)$ dan kompetensi $\left(\mathrm{X}_{2}\right)$ secara bersama-sama diduga berpengaruh signifikan terhadap kinerja karyawan (Y) PT. Mandiri Tunas Finance Palembang.

\section{Metodologi Penelitian}

Pendekatan penelitian ini didasarkan pada metode kuantitatif yang disebut asosiatif, karena telah lama digunakan dengan pemenuhan prinsip-prinsip ilmiah yang konkrit/empiris, logis, dapat diamati, masuk akal, sistematis dan dapat direplikasi sebagai alat penelitian. Analisis tersebut menggunakan analisis asosiatif untuk mengetahui pola hubungan dan / atau pola pengendalian antar variabel pada suatu entitas, guna memahami pengaruh antara variabel terikat $(\mathrm{Y})$ dan variabel bebas $(\mathrm{X})$ atau variabel.

Variabel yang dapat dibedakan dalam analisis ini adalah: 1) variabel dependen adalah variabel yang ditentukan oleh satu atau lebih faktor. Dalam analisis ini, variabel dependen adalah kinerja karyawan 
(Y), 2), variabel independen adalah variabel yang mempengaruhi atau menginduksi pergeseran atau perkembangan variabel dependen. Dalam analisis ini, kompensasi langsung (X1) dan kompetensi merupakan variabel bebas (X2).

Penelitian ini menggunakan skala likert dalam kuesionernya. Sugiyono (2017) menunjukkan bahwa likert adalah skala yang mengukur keyakinan, sudut pandang dan kesan seseorang atau kelompok terhadap fenomena sosial. Penelitian yang selanjutnya disebut variabel kajian justru menentukan pola kemasyarakatan tersebut. Instrumen likert berguna jika peneliti ingin mengukur topik, ide, atau pengalaman secara umum. Agar variabel yang diukur pada instrumen tersebut lebih tepat, efektif dan komunikatif, nilai skala ukur tertentu harus dinyatakan dalam angka.

Penelitian ini dilakukan pada seluruh karyawan PT. Mandiri Tunas Finance Palembang. Pengambilan sampel pada penelitian ini adalah menggunakan teknik sampling jenuh semua populasi dalam penelitian kali ini akan dijadikan sebagai sampel penelitian yang berjumlah sebanyak 56 orang karyawan. Sumber data yang dipergunakan dalam penelitian ini adalah data primer dan sekunder. Teknik pengumpulan data dalam penelitian ini menggunakan angket dan dokumentasi.

Tabel 3. Hasil pengujian validitas

\begin{tabular}{|c|c|c|c|c|c|}
\hline No & Item pertanyaan & $\mathbf{r}_{\text {hitung }}$ & $\mathbf{r}_{\text {tabel }}$ & kriteria & keterangan \\
\hline \multicolumn{6}{|c|}{ Variabel kompensasi langsung } \\
\hline 1. & item 1 & 0,340 & 0,263 & $\mathrm{r}_{\text {hitung }}>\mathrm{r}_{\text {tabel }}$ & valid \\
\hline 2. & item 2 & 0,570 & 0,263 & $r_{\text {hitung }}>r_{\text {tabel }}$ & valid \\
\hline 3. & item 3 & 0,608 & 0,263 & $r_{\text {hitung }}>r_{\text {tabel }}$ & valid \\
\hline 4. & item 4 & 0,673 & 0,263 & $\mathrm{r}_{\text {hitung }}>\mathrm{r}_{\text {tabel }}$ & valid \\
\hline 5. & item 5 & 0,690 & 0,263 & $\mathrm{r}_{\text {hitung }}>\mathrm{r}_{\text {tabel }}$ & valid \\
\hline 6. & item 6 & 0,619 & 0,263 & $r_{\text {hitung }}>r_{\text {tabel }}$ & valid \\
\hline 7. & item 7 & 0,562 & 0,263 & $r_{\text {hitung }}>r_{\text {tabel }}$ & valid \\
\hline 8. & item 8 & 0,675 & 0,263 & $r_{\text {hitung }}>r_{\text {tabel }}$ & valid \\
\hline 9. & item 9 & 0,525 & 0,263 & $r_{\text {hitung }}>r_{\text {tabel }}$ & valid \\
\hline 10. & item 10 & 0,692 & 0,263 & $r_{\text {hitung }}>r_{\text {tabel }}$ & valid \\
\hline \multicolumn{6}{|c|}{ Variabel kompetensi } \\
\hline 1 & item 1 & 0,687 & 0,263 & $r_{\text {hitung }}>r_{\text {tabel }}$ & valid \\
\hline 2 & item 2 & 0,653 & 0,263 & $r_{\text {hitung }}>r_{\text {tabel }}$ & valid \\
\hline 3 & item 3 & 0,723 & 0,263 & $r_{\text {hitung }}>r_{\text {tabel }}$ & valid \\
\hline 4 & item 4 & 0,730 & 0,263 & $r_{\text {hitung }}>r_{\text {tabel }}$ & valid \\
\hline 5 & item 5 & 0,722 & 0,263 & $r_{\text {hitung }}>r_{\text {tabel }}$ & valid \\
\hline 6 & item 6 & 0,720 & 0,263 & $r_{\text {hitung }}>r_{\text {tabel }}$ & valid \\
\hline 7 & item 7 & 0,744 & 0,263 & $r_{\text {hitung }}>r_{\text {tabel }}$ & valid \\
\hline 8 & item 8 & 0,544 & 0,263 & $r_{\text {hitung }}>r_{\text {tabel }}$ & valid \\
\hline 9 & item 9 & 0,675 & 0,263 & $r_{\text {hitung }}>r_{\text {tabel }}$ & valid \\
\hline 10 & item 10 & 0,678 & 0,263 & $r_{\text {hitung }}>r_{\text {tabel }}$ & valid \\
\hline \multicolumn{6}{|c|}{ Variabel kinerja } \\
\hline 1 & item 1 & 0,715 & 0,263 & $r_{\text {hitung }}>r_{\text {tabel }}$ & valid \\
\hline 2 & item 2 & 0,791 & 0,263 & $r_{\text {hitung }}>r_{\text {tabel }}$ & valid \\
\hline 3 & item 3 & 0,685 & 0,263 & $r_{\text {hitung }}>r_{\text {tabel }}$ & valid \\
\hline 4 & item 4 & 0,662 & 0,263 & $\mathrm{r}_{\text {hitung }}>\mathrm{r}_{\text {tabel }}$ & valid \\
\hline 5 & item 5 & 0,816 & 0,263 & $r_{\text {hitung }}>r_{\text {tabel }}$ & valid \\
\hline 6 & item 6 & 0,730 & 0,263 & $r_{\text {hitung }}>r_{\text {tabel }}$ & valid \\
\hline 7 & item 7 & 0,742 & 0,263 & $r_{\text {hitung }}>r_{\text {tabel }}$ & valid \\
\hline 8 & item 8 & 0,755 & 0,263 & $r_{\text {hitung }}>r_{\text {tabel }}$ & valid \\
\hline 9 & item 9 & 0,465 & 0,263 & $r_{\text {hitung }}>r_{\text {tabel }}$ & valid \\
\hline 10 & item 10 & 0,561 & 0,263 & $\mathrm{r}_{\text {hitung }}>\mathrm{r}_{\text {tabel }}$ & valid \\
\hline
\end{tabular}

Sumber: Data diolah menggunakan program SPSS Versi 22 
Berdasarkan temuan pengujian validitas diatas diperoleh hasil semua item kuisioner dari setiap variabel $\mathrm{r}_{\text {hitung }}>\mathrm{r}_{\text {tabel }}$ sehingga semuanya valid dan dapat digunakan untuk mengukur analisis berikutnya.

Tabel 4. Hasil pengujian reliabilitas

\begin{tabular}{|l|c|c|}
\hline \multicolumn{1}{|c|}{ Variabel } & Cronbach's Alpha & N of Items \\
\hline Kompensasi langsung & 0,789 & 6 \\
\hline Kompetensi & 0,872 & 6 \\
\hline Kinerja & 0,868 & 6 \\
\hline
\end{tabular}

Sumber: Hasil dari pengelolahan data dengan SPSS versi 22

Nilai Cronbach alpha lebih tinggi dari 0,60 berdasarkan hasil di atas, maka dapat dikatakan bahwa instrumen penelitian ini dapat diandalkan dalam penelitian ini.

Tabel 5. Hasil uji normalitas

One-Sample Kolmogorov-Smirnov Test

\begin{tabular}{|c|c|c|}
\hline & & $\begin{array}{l}\text { Unstandardiz } \\
\text { ed Residual }\end{array}$ \\
\hline $\mathrm{N}$ & & 56 \\
\hline \multirow[t]{2}{*}{ Normal Parameters ${ }^{a \cdot b}$} & Mean & ,0000000 \\
\hline & Std. Deviation & 2,58703756 \\
\hline \multirow[t]{3}{*}{ Most Extreme Differences } & Absolute & .077 \\
\hline & Positive &, 077 \\
\hline & Negative &,- 066 \\
\hline Test Statistic & & .077 \\
\hline Asymp. Sig. (2-tailed) & & $.200^{c . d}$ \\
\hline
\end{tabular}

a. Test distribution is Normal.

b. Calculated from data.

Sumber: Hasil dari pengelolahan data dengan SPSS versi 22

Berdasarkan output tabel 4 diatas dapat diketahui bahwa nilai signifikansi (Asymp. Sig 2-tailed) sebesar 0,200. Karena nilai signifikan lebih dari 0,05, maka nilai residual berdistribusi normal.

Tabel 6. Hasil uji multikolinieritas

\begin{tabular}{|c|c|c|c|c|c|c|c|c|}
\hline \multirow[b]{2}{*}{ Model } & & \multicolumn{2}{|c|}{ Unstandardized Coefficients } & \multirow{2}{*}{$\begin{array}{c}\begin{array}{c}\text { Standardized } \\
\text { Coefficients }\end{array} \\
\text { Beta }\end{array}$} & \multirow[b]{2}{*}{$t$} & \multirow[b]{2}{*}{ Sig. } & \multicolumn{2}{|c|}{ Collinearity Statistics } \\
\hline & & $B$ & Std. Error & & & & Tolerance & VIF \\
\hline \multirow[t]{3}{*}{1} & (Constant) & 4,898 & 4,606 & & 1,063 &, 292 & & \\
\hline & $\begin{array}{l}\text { Kompensasi Langsung } \\
\text { (X1) }\end{array}$ &, 369 &, 113 &, 361 & 3,264 &, 002 &, 671 & 1,491 \\
\hline & Kompetensi (X2) &, 503 &, 115 &, 483 & 4,362 &, 000 &, 671 & 1,491 \\
\hline
\end{tabular}

a. Dependent Variable: Kinerja Karyawan ( $)$

Sumber: Hasil dari pengelolahan data dengan SPSS versi 22

Pada tabel 5 dapat dilihat bahwa dari hasil ujui multikolinieritas di atas, nilai tolerance $>$ dari 0,10 dan nilai variance inflaction factor (VIF) $<10$ dari variabel. Pada variabel kompensasi langsung $\left(\mathrm{X}_{1}\right)$ dan kompetensi $\left(\mathrm{X}_{2}\right)$ nilai tolerance sebesar $0,671>0,10$. Sedangkan, nilai VIF pada variabel kompensasi langsung $\left(\mathrm{X}_{1}\right)$ dan kompetensi $\left(\mathrm{X}_{2}\right)$ sebesar 1,491 < 10. Maka dapat disimpulkan bahwa tidak terjadi multikolinieritas pada penelitian ini. 
Gambar 2. Hasil uji heteroskedasitas

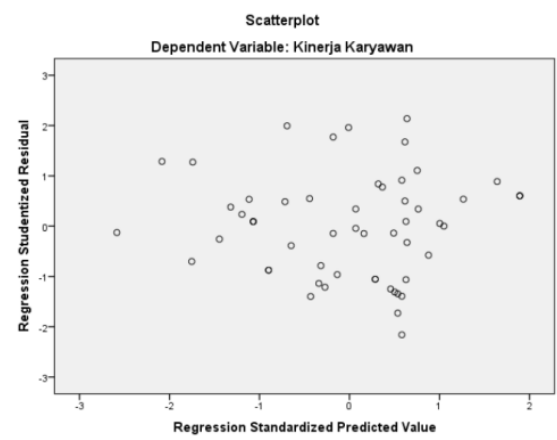

Sumber: Hasil dari pengelolahan data dengan SPSS versi 22

Pada gambar 2 di atas dapat dilihat bahwa titik-titik yang menyebar secara acak, maka dapat disimpulkan tidak terjadi heteroskedasitas pada uji penelitian. Dengan demikian kuisioner variabel kompensasi langsung, kompetensi, dan kinerja dapat dipakai sebagai alat ukur untuk analisis selanjutnya.

\section{Hasil dan Pembahasan}

Setelah kuisioner disebar dan dianalisis, diperoleh hasil sebagai berikut:

Tabel 7. Hasil analisis regresi linear berganda

Coefficients $^{\mathrm{a}}$

\begin{tabular}{|c|c|c|c|c|c|c|}
\hline \multirow{2}{*}{\multicolumn{2}{|c|}{ Model }} & \multicolumn{2}{|c|}{ Unstandardized Coefficients } & \multirow{2}{*}{$\begin{array}{c}\begin{array}{c}\text { Standardized } \\
\text { Coefficients }\end{array} \\
\text { Beta }\end{array}$} & \multirow[b]{2}{*}{$t$} & \multirow[b]{2}{*}{ Sig. } \\
\hline & & $\mathrm{B}$ & Std. Error & & & \\
\hline \multirow[t]{3}{*}{1} & (Constant) & 4,898 & 4,606 & & 1,063 &, 292 \\
\hline & Kompensasi Langsung &, 369 &, 113 & ,361 & 3,264 &, 002 \\
\hline & Kompetensi &, 503 & .115 & .483 & 4,362 &, 000 \\
\hline
\end{tabular}

a. Dependent Variable: Kinerja Karyawan

Sumber: Hasil dari pengelolahan data dengan SPSS versi 22

Dari tabel diatas menunjukkan hasil perhitungan koefisien regresi linier berganda diperoleh nilai koefisien regresi untuk kompensasi langsung sebesar 0,369 dan nilai koefisien regresi untuk kompetensi sebesar 0,503. Serta konstanta sebesar 4,898 berdasarkan nilai tersebut diperoleh

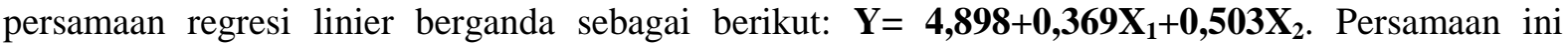
menunjukkan koefesien regresi dari 2 (dua) variabel bebas $\left(b_{1}\right.$ dan $\left.b_{2}\right)$ bertanda positif $(+)$. Bilangan konstanta (a) mempunyai nilai sebesar 4,898 menyatakan bahwa jika mengabaikan kompensasi langsung $\left(\mathrm{X}_{1}\right)$ dan kompetensi $\left(\mathrm{X}_{2}\right)$ maka nilai kinerja karyawan adalah 4,898. Jadi, tetap ada kinerja karyawan walaupun nilai $\mathrm{X}_{1}$ dan $\mathrm{X}_{2}$ bernilai nol (0) terhadap $\mathrm{Y}$.

Koefesien $\mathrm{X}_{1}$ menunjukkan bahwa variabel kompensasi langsung $\left(\mathrm{X}_{1}\right)$ berpengaruh positif terhadap kinerja karyawan. Jika kompensasi langsung dinaikkan satu satuan maka kinerja karyawan akan naik sebesar 0,369, dan sebaliknya jika kompensasi langsung diturunkan sebesar satu satuan maka kinerja karyawan akan turun sebesar 0,369. Artinya semakin besar kompensasi langsung karyawan PT. Mandiri Tunas Finance Palembang, maka kinerja karyawan akan meningkat. Bahwa pengaruhnya positif yang artinya apabila kompensasi langsung naik, maka kinerjanya naik atau meningkat dan sebaliknya jika, kompensasi langsung turun maka kinerja juga turun. 
Koefesien $\mathrm{X}_{2}$ menunjukkan bahwa variabel Kompetensi $\left(\mathrm{X}_{2}\right)$ berpengaruh positif terhadap kinerja karyawan. Jika kompetensi dinaikkan satu satuan maka kinerja karyawan akan naik sebesar 0,503 dan sebaliknya jika kompetensi diturunkan sebesar satu satuan maka kinerja karyawan akan turun sebesar 0,503. Artinya semakin besar kompetensi karyawan PT. Mandiri Tunas Finance Palembang maka, kinerja karyawan akan meningkat. Bahwa hubungannya positif yang artinya apabila kompetensi naik maka kinerjanya naik atau meningkat dan sebaliknya jika, kompetensi turun maka kinerja juga turun.

Nilai $\mathrm{t}_{\text {hitung }}$ kompensasi langsung terhadap kinerja karyawan sebesar 3,264 sementara untuk $\mathrm{t}$ tabel dengan sig. $a=0,05$ dan $\mathrm{df}=\mathrm{n}-\mathrm{k}$, yaitu $56-3$, maka didapat $\mathrm{t}_{\text {tabel }}$ sebesar 1,674. Nilai $\mathrm{t}_{\text {hitung }}$ lebih besar dari $\mathrm{t}_{\text {tabel }}(3,264>1,674)$. Dan sig. $0,002<0,05$ maka, $\mathrm{H}_{0}$ ditolak dan $\mathrm{H}_{\mathrm{a}}$ diterima artinya ada pengaruh positif dan signifikansi pada variabel kompensasi langsung terhadap kinerja karyawan. Kompensasi langsung merupakan kompensasi yang diterima oleh karyawan yang mempunyai hubungan langsung dengan pekerjaan, yaitu gaji, upah, lembur atau insentif dan bonus. Hasibuan (2017) mengatakan bahwa tujuan pemberian kompensasi antara lain adalah untuk kepuasan kerja karyawan yang nantinya akan menjaga stabilitas karyawan sehingga bisa menekan angka turn-over . Selain itu, karyawan juga akan terhindar dari pengaruh serikat buruh dan hanya berkonsentrasi pada pekerjaannya saja. Hasil penelitian ini mendukung hasil penelitian Fauziah, Sunuharyo \& Utami (2016), Zulkarnaen \& Herlina (2018) bahwa kompensasi langsung berpengaruh positif dan signifikan terhadap kinerja karyawan.

Nilai $\mathrm{t}$ hitung kompetensi terhadap kinerja karyawan sebesar 4,362 sementara untuk $\mathrm{t}_{\text {tabel }}$ dengan sig. $a$ $=0,05$ dan $\mathrm{df}=\mathrm{n}-\mathrm{k}$, yaitu $56-3$, maka didapat $\mathrm{t}_{\text {tabel }}$ sebesar 1,674. Nilai $\mathrm{t}_{\text {hitung }}$ lebih besar dari $\mathrm{t}_{\text {tabel }}$ $(4,362>1,674)$. Dan sig. $0,000<0,05$ maka, $H_{0}$ ditolak dan $\mathrm{H}_{\mathrm{a}}$ diterima artinya ada pengaruh positif dan signifikansi pada variabel kompetensi terhadap kinerja karyawan. Kompetensi merupakan suatu kemampuan untuk melaksanakan atau melakukan suatu pekerjaan yang dilandasi atas keterampilan dan pengetahuan serta didukung oleh sikap kerja yang baik oleh pekerjaan tersebut Wibowo (2014). Kompetensi berhubungan dengan kinerja yang efektif dalam suatu pekerjaan atau situasi. Artinya kompetensi dalam penelitian ini sebagai karakteristik yang memanfaatkan kemampuan dan keterampilan guna meningkatkan kinerja karyawan, $\mathrm{Hal}$ ini berarti $\mathrm{H}_{\mathrm{a}}$ diterima dan $\mathrm{H}_{0}$ ditolak yang artinya variabel kompetensi berpengaruh terhadap kinerja karyawan. Hasil penelitian ini mendukung hasil penelitian Kartika \& Sugiarto (2014), Manik \& Syafrina (2018) bahwa terdapat pengaruh positif signifikan kompetensi terhadap kinerja karyawan, yang berarti kompetensi menjadi salah satu bagian penting yang dapat meningkatkan kinerja karyawan.

Tabel 7 Hasil uji F

ANOVA $^{\mathrm{a}}$

\begin{tabular}{|ll|r|r|r|r|l|}
\hline Model & & \multicolumn{1}{c|}{$\begin{array}{c}\text { Sum of } \\
\text { Squares }\end{array}$} & \multicolumn{1}{c|}{ df } & Mean Square & F & Sig. \\
\hline 1 & Regression & 476,452 & 2 & 238,226 & 34,300 &, $000^{\mathrm{b}}$ \\
& Residual & 368,102 & 53 & 6,945 & & \\
& Total & 844,554 & 55 & & & \\
\hline
\end{tabular}

a. Dependent Variable: Kinerja Karyawan $(n)$

b. Predictors: (Constant), Kompetensi $(\mathrm{X} 2)$, Kompensasi Langsung $(\mathrm{X} 1)$

Sumber: Hasil dari pengelolahan data dengan SPSS versi 22

Berdasarkan hasil Uji F pada tabel 7 di atas menunjukkan bahwa nilai $\mathrm{F}$ sebesar 34,300 sementara untuk $\mathrm{f}_{\text {tabel }}$ dengan sig. $a=0,05 \mathrm{dan} \mathrm{df}=2$ maka didapat $\mathrm{f}_{\text {tabel }}$ sebesar 3,171. Nilai $\mathrm{f}_{\text {hitung }}$ lebih besar dari $\mathrm{f}_{\text {tabel }}(34,300>3,171)$ dan Sig. 0,000 dapat disimpulkan model regresi ini dapat digunakan. Karena tingkat sig. lebih kecil dari $0,05(0,000<0,05)$ bahwa hasilnya $\mathrm{H}_{0}$ ditolak dan $\mathrm{H}_{\mathrm{a}}$ diterima sehingga dapat dikatakan bahwa terdapat pengaruh positif signifikan kompensasi langsung dan kompetensi secara bersama-sama terhadap kinerja karyawan PT. Mandiri Tunas Finance Palembang. 
Hasil ini sejalan dengan penelitian Mudayana \& Suryoko (2015), Dhermawan, Sudibya, \& Utama (2012) hasilnya kompetensi dan kompensasi berpengaruh positif dan signifikan terhadap kinerja karyawan.

\section{Simpulan}

Tujuan dari penelitian ini adalah untuk menilai pengaruh dari kompensasi langsung dan kompetensi terhadap kinerja pegawai pada PT. Mandiri Tunas finance Palembang. Kesimpulan dapat diambil dari hasil analisis dan diskusi dari hasil penelitian bahwa kompensasi langsung memiliki nilai $t_{\text {hitung }}>t_{\text {tabel }}$ maka $\mathrm{H}_{0}$ ditolak dan $\mathrm{H}_{\mathrm{a}}$ diterima artinya terdapat pengaruh positif, signifikan kompensasi langsung terhadap kinerja karyawan PT. Mandiri Tunas Finance Palembang. Selanjutnya kompetensi memiliki nilai $t_{\text {hitung }}>t_{\text {tabel }}$ maka $\mathrm{H}_{0}$ ditolak dan $\mathrm{H}_{\mathrm{a}}$ diterima artinya terdapat pengaruh positif, signifikan kompetensi terhadap kinerja karyawan PT. Mandiri Tunas Finance Palembang. Dan secara simultan kompensasi langsung dan kompetensi memiliki nilai $f_{\text {hitung }}>f_{\text {tabel }}$ artinya terdapat pengaruh positif, signifikan secara kompensasi langsung dan kompetensi secara bersama-sama terhadap kinerja pegawai PT. Mandiri Tunas Finance Palembang.

Dengan demikian untuk meningkatkan kinerja pegawai sebaiknya pemimpin perusahaan berusaha meningkatkan kompensasi langsung dan kompetensi pegawai melalui upaya peningkatan pengetahuan, keterampilan dan sikap, serta menyesuaikan antara permintaan dan penawaran tenaga kerja, meningkatkan kompensasi sesuai dengan kemampuan perusahaan, dan melakukan penyesuaian pekerjaan sesuai dengan kompetensi yang dimiliki oleh pegawai. Hal ini perlu dilakukan dengan harapan dapat memotivasi pegawai untuk melakukan pelayanan yang baik kepada konsumen, dan dapat mewujudkan peningkatan kinerja untuk mencapai target dan sesuai dengan standar pekerjaan yang telah ditetapkan perusahaan.

\section{Daftar Pustaka}

Bintoro, \& Daryanto. (2017). Manajemen penilaian kinerja. Yogyakarta: Gava Media.

Darmawati, T. (2013). Pengaruh kompetensi terhadap kinerja pegawai Fakultas Ekonomi Universitas PGRI Palembang. Jurnal Media Wahana Ekonomika, Vol. 10(No. 1), 71-80.

Dhermawan, A. A., Sudibya, I. A., \& Utama, I. M. (2012). Pengaruh motivasi, lingkungan kerja, kompetensi, dan kompensasi terhadap kepuasan kerja dan kinerja pegawai di lingkungan kantor dinas pekerjaan umum Provinsi Bali. Matrik: Jurnal Manajemen, Strategi Bisnis dan Kewirausahaan, Vol. 6(No. 2), 173-184.

Edison, E. Y. (2016). Manajemen Sumber Daya Manusia. Bandung: Alfabeta.

Fahmi, I. (2016). Pengantar manajemen sumber daya manusia : konsep dan kinerja. Jakarta: Mitra Wacana Media.

Fauziah, S., Sunuharyo, B. S., \& Utami, H. N. (2016). Pengaruh kompensasi langsung dan kompensasi tidak langsung terhadap motivasi kerja karyawan dan kinerja karyawan (Studi pada AJB Bumiputera 1912 Cabang Celaket Malang). Jurnal Administrasi Bisnis (JAB)|, Vol. 37(No. 1), 178-187.

Hasibuan, M. S. (2017). Manajemen sumber daya manusia. Jakarta: Bumi Aksara.

Inova, M., \& Jayanti, R. D. (2019). Pengaruh kompetensi dan kompensasi terhadap kinerja karyawan PT Maan Ghodaqo Shiddiq Lestari Jombang. JMD: Jurnal Riset Manajemen Dan Bisnis Dewantara, Vol. 2(No. 1), 1-12.

Kadarisman, M. (2014). Manajemen kompensasi. Jakarta: Rajagrafindo Persada.

Kartika, L. N., \& Sugiarto, A. (2014). Pengaruh Tingkat Kompetensi Terhadap Kinerja Pegawai Administrasi Perkantoran. Jurnal Ekonomi Dan Bisnis, Vol. 17(No. 1), 73-90.

Mangkunegara, A. P. (2014). Manajemen Sumber Daya Manusia Perusahaan. Bandung: PT. Remaja Rosdakarya. 
Manik, S., \& Syafrina, N. (2018). Pengaruh kompetensi terhadap kinerja dosen sekolah tinggi ilmu ekonomi Riau. Jurnal Ilmiah Ekonomi dan Bisnis, Vol. 11(No. 1), 1-6.

Moeheriono. (2014). Pengukuran kinerja berbasis kompetensi. Jakarta: Rajagrafindo Persada.

Mudayana, F. I., \& Suryoko, S. (2015). Pengaruh Kompetensi, Kompensasi, dan Lingkungan Kerja terhadap Kinerja Karyawan melalui Motivasi Kerja Sebagai Variabel Intervening (Studi Kasus pada Karyawan Bagian Produksi PT. Sai Apparel Industries Semarang). Jurnal Ilmu Administrasi Bisnis, Vol.5(No.1), 300-312.

Sinambela, L. P. (2018). Manajemen sumber daya manusia. Jakarta: PT. Bumi Aksara.

Sugiyono. (2017). Metode penelitian kuantitatif, kualitatif, dan R\&D. Bandung: Alfabeta.

Wibowo. (2014). Manajemen kinerja. Jakarta: Rajagrafindo Persada.

Zulkarnaen, W., \& Herlina, R. (2018). Pengaruh kompensasi langsung dan kompensasi tidak langsung terhadap kinerja karyawan bagian staff operasional PT Pranata Jaya Abadi Banjaran. Jurnal Ilmiah MEA (Manajemen, Ekonomi, \& Akuntansi), Vol. 2(No. 2), 90-114.

\section{Acknowledgement}

PT. Mandiri Tunas Finance Palembang, Rektor, Dekan Fakultas Ekonomi dan Program Studi Manajemen PGRI Universitas Palembang, yang telah menawarkan kesempatan dan bantuan untuk proyek penelitian ini, kami mengucapkan terima kasih dan sekali lagi terima kasih. Proyek penelitian ini menggunakan dana mandiri. Selain itu, kami juga berterima kasih kepada instruktur manajemen lainnya yang telah membantu menyelesaikan proyek penelitian ini dalam jangka waktu yang ditentukan.

\section{Copyright Disclaimer}

The authors, with the original publishing rights provided to the journal, retain copyright for this paper. 